\title{
EIF4A1 wt Allele
}

National Cancer Institute

\section{Source}

National Cancer Institute. EIF4A1 wt Allele. NCI Thesaurus. Code C104191.

Human EIF4A1 wild-type allele is located in the vicinity of $17 \mathrm{p} 13$ and is approximately $6 \mathrm{~kb}$ in length. This allele, which encodes eukaryotic initiation factor $4 \mathrm{~A}-\mathrm{I}$, plays a role in translation initiation. 